\title{
THE TWENTY-FOURTH ANNUAL CONVENTION
}

The first Pacific Coast convention of the Catholic Theological Society of America was held at the Sheraton Palace Hotel in San Francisco, June 16-19, 1969. The theme was The Ministry; the program was outstanding; the attendance was quite good; and the response was gratifying to the convention planners.

The first general session of the convention was convened Tuesday, June 17, at 9:30 A.M. by Austin Vaughan, President of the Society. Archbishop Joseph T. McGucken warmly welcomed the Society to the city of St. Francis. He encouraged the theologians in their function of stimulating and helping the magisterium grow; of reading the signs of the times for the preaching of the Gospel; and of being an instrument of the magisterium in spreading their teaching.

Peter Chirico of St. Thomas Seminary, Kenmore, Washington, delivered the first major address of the convention, titled Theological Method and the Nature of Ministry. The second paper read in general session was The Biblical Theology of Ministry in the New Testament by Richard Dillon of St. Joseph's Seminary, Yonkers, New York. President Vaughan introduced Remi de Roo, Bishop of Vancouver, a member of the Society who was attending the convention engaging actively in the theological exchange. A concelebrated convention Mass for the deceased members of the Society was offered at the noon hour, with Gerald Van Ackeren, S.J. the principal concelebrant.

The elective seminars offered Tuesday afteroon included the following:

1. Priesthood and Ministry from the New Testament to Nicea, by Carl Armbruster of Bellarmine School of Theology, North Aurora, Illinois. 
2. Marriage and Celibacy in the Service of the Church, by James Mulligan of Mt. St. Mary Seminary, Emmitsburg, Maryland.

3. Pentecostalism and Catholicism, by Edward O'Connor of the University of Notre Dame.

After an intermission, additional theme seminars were offered.

1. Priesthood and Religious Life, by Cletus Wessels of Aquinas Institute of Theology, Dubuque.

2. The Concept of Validity in the Ministry, by Joseph Powers, of Alma College, Los Gatos, California.

3. Ministry and the World Council of Churches, by Keith Bridston of the Graduate Theological Union at Berkeley.

The first day of the convention was concluded with the traditional buffet dinner at 5:30 P.M.

The first woman member of the Society to address a CTSA convention was Agnes Cunningham, S.S.C.M. of St. Mary of the Lake Seminary, Illinois, who gave the first talk on the second day of the convention. Her topic was The Ministry of Woman in the Church; and the scholarly paper received extensive press coverage.

\section{Annual Business Meeting}

The annual business meeting of the Society took place at 11:45 A.M., Wednesday, June 18. The meeting was called to order by Austin Vaughan, who had appointed Joseph Nearon parliamentarian. Monsignor Vaughan delivered the presidential address, in which he analyzed the problems and tasks of Catholic theology in 1969 (see above). Warren Reich gave the Secretary's Report, in which he announced among other things the formation of the new Council on the Study of Religion. (For an explanation of this organization, the actions of the Board of Directors, and the ratification by the membership, see the article above.) Brother Luke Salm gave the treasurer's report (see below). The report of the Committee on Admissions was read by Warren Reich, who noted that all applications for membership were reviewed by the Committee with the following recommendations:

77 applications for active membership approved;

9 applications for associate membership approved. 
Father Reich made the motion that these applications be accepted and that the applicants be formally notified of their membership in the society. The motion was seconded and passed unanimously by the assemblage.

The newly approved active members are:

Rev. Eugene J. Ahern, S.J.

Rev. John Alesandro

Rev. Louis A. Arceneaux, C.M.

Mr. Morris J. Augustine

Rev. George K. Aziz, S.J.

Mr. Eugene T. Boneski

Rev. John P. Boyle

Rev. Lawrence E. Burns

Rev. Patrick J. Burns, S.J.

Rev. Ralph E. Cahouet, O.P.

Rev. X. William Carroll

Rev. Robert E. Carter, S.J.

Bro. James P. Clifton, C.F.X.

Rev. Brendan Comiskey, SS.CC.

Rev. Nicholas Crotty, C.P.

Rev. Joseph L. Cunningham

Rev. Charles R. Dautremont

Rev. Jerome M. Dittberner,

O.F.M.Conv.

Rev. Laurence P. Dolan

Rev. John J. Donohue

Rev. Thomas E. Dubay, S.M.

Rev. Edward P. Echlin, S.J.

Mr. David P. Efroymson

Rev. Thomas Ellerman, S.M.

Rev. Charles P. Essman

Rev. Peter Esterka

Sr. Amata Fabbro, O.P.

Rev. Richard W. Ferris

Rev. David Fitch, S.J.

Rev. Edmund J. Fitzpatrick
Rev. Robert S. Flagg

Rev. Joseph P. Foth, S.M.

Rev. Edward M. Gaffney

Rev. George P. Graham

Rev. Bertram F. Griffin

Rev. Michael D. Guinan, O.F.M.

Rev. Vincent C. Horrigan, S.J.

Rev. Raymond B. Kemp

Rev. Joseph R. Lerch, S.J.

Rev. Berard P. Lyons, T.O.R.

Rev. Richard P. McBrien

Rev. Kilian P. McDonnell, O.S.B.

Rev. James McGoldrick, S.M.

Rev. Lawrence J. Madden, S.J.

Rev. Colin J. Maloney, S.J.

Rev. Timothy A. Mannello

Rev. Richard G. Marimon

Rev. John A. Melloh

Rev. John C. Mitchell

Rev. C. Thomas Moore, O.P.

Bro. Gabriel E. Murphy, F.S.C.

Rev. Carmelo Muscat

Rev. Richard M. Nardone

Rev. Charles E. Nolan, O.Carm.

Rev. John F. O'Grady, C.M.

Rev. Joseph M. Powers, S.J.

Rev. Bernard P. Prusak

Rev. Lawrence M. Purcell

Rev. James M. Quigley, S.J.

Rev. Denis M. Regan 
Rev. Joseph J. C. Sammut

Rev. Sal L. Sansone, C.M.

Rev. Carmel Sant

Mr. William J. Sullivan

Rev. Jerome P. Theisen, O.S.B.

Rev. Henry V. Sattler, C.SS.R.

Rev. Theodore, J. Vittoria, S.S.P.

Rev. David Scanlin, O.M.I.

Rev. Michael J. Walsh, C.M.

Rev. Dominic F. Scotto, T.O.R. Mr. Thomas E. Wangler

Rev. John M. Shea

Rev. Duane J. Weiland

Dr. Ernest Skublics

Rev. W. Barry Smith

Rev. Joseph M. Whalen

Rev. Paul J. Whitney

The newly approved associate members are:

Rev. Paul I. Bechtold, C.P.

Rev. Gerald D. Coleman, S.S.

Rev. Thomas L. Dorney, O.Carm.

Rev. James E. Hannan, O.S.A. Rev. Michael Higgins
Rev. Richard A. Mevissen, C.SS.R.

Rev. Robert J. Richards

Rev. Gerald J. Ryle

Rev. Joseph L. Taranto

By a voice vote the membership elected to honorary membership Most Rev. Joseph T. McGucken, S.T.D., LL.D., Archbishop of San Francisco.

Msgr. Daniel Flynn, chairman of the Committee on Nominations (the other members of that Committee being Cletus Wessels, O.P. and Thomas Stanks, S.S.) gave the following committee report:

for President: Rev. Charles E. Curran

for Vice-President: Rev. Richard A. McCormick, S.J. and Rev. John P. Whalen

for Secretary: Rev. Warren T. Reich, S.T.

for Treasurer: Bro. C. Luke Salm, F.S.C.

for the Board of Directors (to serve a two-year term): Msgr. Austin B. Vaughan (as out-going President), Rev. Eugene Van Antwerp, S.S., Sr. Agnes Cunningham, S.S.C.M., Rev. Christopher Kiesling, O.P., and Rev. Hugh McElwain, O.S.M.

Brother Luke Salm explained the voting procedures. Msgr. Vaughan asked if there were additional nominations from the floor for the office of President. Rev. John Ruef, C.SS.R. nominated Rev. John P. 
Whalen, the nomination was seconded, and the nominations were declared closed. Father Charles E. Curran was elected President by written ballot, receiving 99 votes, while Father Whalen received 36 votes. No further nominations having been made for the position of Vice-President, the nominations were declared closed, and Father McCormick was elected Vice-President by receiving 94 votes, as compared with 43 votes cast for Father Whalen. Father Warren Reich and Brother Luke Salm were re-elected Secretary and Treasurer respectively by unanimous voice vote. Msgr. Austin Vaughan was unanimously elected to the Board of Directors by voice vote. Also elected to the Board were Sr. Agnes Cunningham (93 votes) and Father Eugene Van Antwerp (71 votes).

Rev. Wilfrid Dewan, C.S.P. gave a report on the meetings of the Baltimore-Washington Region, and Rev. Geroge Malone spoke of the activities of the Chicago Region members. Rev. Adam Maida, President of the Canon Law Society of America, gave a report on the recent activities of his Society, particularly the many symposia, workshops and study projects which they have sponsored and are planning. Noting that the theologians have been the backbone of many of their projects, Father Maida made some concrete proposals as to how the CTSA could cooperate with the Canon Law Society on projects which would make substantial contributions to the good of the Church.

The following resolution was made by Nathan Kollar, seconded by Xavier Colavechio, and unanimously approved by the membership present at the meeting:

WHEREAS the Christian community should be an example of love and justice in the affairs of men; and

WHEREAS we as theologians should be an aid to the Bishops in the exercise of their pastoral ministry;

BE IT RESOLVED that The Catholic Theological Society of America urgently recommends to the Bishops of the United States that equitable procedures for due process be adopted and implemented in cases of theological and disciplinary disputes within the Church.

From the tone of the discussion, this resolution was seen as affecting theological and disciplinary disputes between or among hierarchy, 
theologians, clergy, religious and laity. (In subsequent action, Father Warren Reich transmitted this resolution to John Cardinal Dearden, President of the National Conference of Catholic Bishops. Cardinal Dearden replied: "As you know, the bishops have encouraged the study that has been undertaken by the members of the Canon Law Society. Hopefully from this research and from other studies that are being made in other parts of the country, we may find a procedure that will be of help to us in many difficult situations.")

Msgr. Vaughan announced that the CTSA Committee for Liaison with the Bishops' Doctrinal Committee has been re-constituted. Father Carl Peter will continue to serve as Secretary of the Committee, and the other members of the Committee will be the President, the Vice-President, and the Secretary of the Society. Brother Luke Salm announced that the next convention will be held June 16-18, 1970 at the Pick-Fort Shelby Hotel in Detroit.

The business meeting was adjourned at 1:30 P.M.

\section{Convention Program Continued}

The Wednesday afternoon convention schedule continued with the following Elective Theme Seminars:

1. Theology of the Presbyterium, by Joseph O'Brien of St. Mary of the Lake Seminary, Illinois.

2. The Permanence of the Ministry, by Christopher Kiesling of Aquinas Institute of Theology, Dubuque.

At 8:30 P.M. there was a public session on The Question of Intercommunion, with papers by Francis Buckley of the University of San Francisco and Toivo Hariumpaa of Pacific Lutheran Theological Seminary. A lively discussion ensued; and Father Buckley's theories received national attention through extensive press coverage.

The final session of the convention on Thursday morning, June 19, featured a dialog on The Teaching Role of the Magisterium and of Theologians between John Quinn, Auxiliary Bishop of San Diego, and Richard McCormick of Bellarmine School of Theology. The conventioneers welcomed this unique sort of lively exchange which climaxed a well planned and highly appreciated program. 
Upon the motion made by President Vaughn, the membership gave a vote and applause of thanks to Rev. Theodore Taheny of the University of San Francisco and to his devoted and hard-working staff who had taken care of so many details for convention arrangements, particularly for the Eucharistic celebrations and the registration.

In-coming President Charles Curran expressed the gratitude of the Society to Msgr. Austin Vaughn, the out-going President, and to Fathers McKeever, Topmoeller and Whalen, the out-going members of the Board of Directors. He also spoke of the projects which lie before the Society and its Board of Directors for the coming year, especially the revision of the Constitution.

Before adjourning the 1969 convention, Msgr. Vaughan announced that the Committee on the Cardinal Spellman Award had selected Rev. Richard A. McCormick, S.J. of Bellarmine School of Theology, North Aurora, Illinois to be honored as the Outstanding Theologian of the Year.

\section{Citation for the Cardinal Spellman Award}

The man to whom the Catholic Theological Society of America pays its most significant theological tribute in the year 1969 is a theologian for our season. Having taught Christian morals for just a little over a decade, he has helped moral theology to pass from excessive casuistry to the status of a living and inspiring science, by respecting tradition while being keenly sensitive to the present and the present needs of the Christian community. Particularly through his writings in Theological Studies, he has been a leader among moral theologians. He has grown increasingly more sensitive to the inter-disciplinary dimensions of his craft, of the need moralists have of the exact and behavioral sciences; and he has given theological impetus to the ecumenical dialogue as a member of the National Catholic Commission for CatholicMethodist Dialogue.

In the past year this theologian of Christian living has involved himself in and brought much balance to the bishoptheologian tension and the right-to-dissent issue. In print and on the dais, in conversation and consultation, with hierarchy and laity, he has never lost his scholarly cool while affirming 
his passionate convictions. He has shown himself persuasive yet ever open to persuasion.

Born in Toledo, Ohio in 1922, and having earned degrees at Loyola of Chicago and the Gregorian of Rome, our honoree is currently professor of moral theology at Bellarmine School of Theology in North Aurora, Illinois. His numerous publications include chapters and articles in $A l l$ Things to All Men, The Problem of Population, The Future of Ethics and Moral Theology, Norm and Context in Christian Ethics, The New Catholic Encyclopedia, Theological Studies, America, and The Homiletic and Pastoral Review. $\mathrm{He}$ is now general editor (along with Yale's James Gustafson and Princeton's Paul Ramsey) of Studies in Christian Ethics, and serves as a member of the Board of Trustees of the University of Detroit.

The Catholic Theological Society of America is proud to present the Cardinal Spellman Award for 1969 to a man who symbolizes the fact that American Catholic moral theology is coming of age: Richard Arthur McCormick of the Society of Jesus.

WARREN T. REICH, S.T.

Secretary, CTSA

The Catholic University of America

Washington, D. C. 